in the present study as much as $81 \%$ of the patients preferred propranolol and none preferred the placebo. That does not exclude any placebo effect but it does show that propranolol has antimigraine properties. Several of the patients who improved on propranolol complained that their migraine attacks increased in frequency, intensity, and duration during the start of the placebo period. Therefore there is little reason to suspect a carry-over effect of propranolol.

The optimal antimigraine dose of propranolol is not known. We, like Lund-Larsen (1969), found doses as low as $40-60 \mathrm{mg}$ daily effective. Doses of more than $160 \mathrm{mg}$ daily were not given. Propranolol is effective in migraine probably because it prevents vasodilatation of the cerebral arteries. Seemingly the various beta-blockers act differently in migraine. The pharmacological properties of the different beta-blocking drugs are known to differ. Propranolol has no intrinsic sympathomimetic activity (Johnson, 1967; Barret, 1971) and its action on the peripheral vascular beta-receptors is said to be greater than that of other beta-blocking agents. Both pindolol and practolol are cardioselective (Barret, 1971; Beumer and Hardouck, 1971; Gunther and Kamburoff, 1971; McNeill, 1971) and have little effect at the peripheral vascular beta-receptors.

The placebo and propranolol (Inderal) were kindly supplied by Imperial Chemical Industries Ltd. We thank the company for their help in randomizing the substances. We also thank Cand. Real. Harald Horten, department of statistics, University of Trondheim $-\mathrm{NTH}$, for the statistical evaluation.

\section{References}

Ad Hoc Committee. (1962). Fournal of the American Medical Association, $179,717$.

Barret, A. M. (1971). Postgraduate Medical fournal, Supplement, 47, 7. Bekes, M., et al. (1968). Lancet, 2, 980.

Beumer, H. M. and Hardonk, H. J. (1971). Medizinische Klinik, 66, 1804

Beumer, H. M., and Hardon, P. O. (1972). Headache, 12, 15.

Ekbom, K., and Lundberg, P. O. (1972). Headache, 12, 15. Faboratory and Clinical Investigation, Supplement, 102, 96.

Friedman, A. P., and Morritt, H. (1957). fournal of the American Medical Association, 163, 1111

Günthner, W., and Kamburoff, P. L. (1971). Therapiewoche, 21, 4060 Johnson, G. (1967). Acta Pharmacologica et Toxicologica, 25, Suppl. 2, 63. Lund-Larsen, P. C. (1969). Tidsskrift for den Norske Laegeforening, 89, 1121. Malvea, B. P., Owon, N., and Graham, J. R. (1973). Headache, 12, 163. McNeill, R. S. (1971). Postgraduate Medical fournal, Supplement, 47, 14.

Piovella, C. (1972). Research and Clinical Studies in Headache, 3, 277.

Rabkin, R et al (1966). American fournal of Cardiology, 18, 370.

Sjaastad, O., and Stensrud, P. (1972). Acta Neurologica Scandinavica, 48, 124

Weber, R. B., and Reinmuth, O. M. (1971). Neurology, 21, 404

Weber, R. B., and Reinmuth,

Wolff, H. G. (1963). Headache and other head pain, 2nd. ed. New York, Oxford University Press.

Wykes, P. (1968). Practitioner, 200, 702.

\title{
Response to Influenza Vaccine by Renal Transplant Patients
}

\author{
R. N. P. CARROLL, \\ S. D. MARSH, \\ E. P. N. O'DONOGHUE, \\ D. C. BREEZE, \\ R. SHACKMAN
}

British Medical fournal, 1974, 2, 701-703

\section{Summary}

Twenty-five renal transplant patients and 17 controls were vaccinated with influenza vaccine. Antibody titres were estimated before and one, three, and 12 months after vaccination. On the basis of antibody titre measurements the transplant group showed a similar qualitative and quantitative response to that of the controls. No rejection episodes occurred among the transplant patients as a result of vaccination and nobody in the trial developed influenza. We conclude that it is safe to vaccinate transplant patients with an inactivated influenza vaccine and that protection (haemagglutination-inhibiting antibody) can be induced.

\section{Introduction}

In 1969 we vaccinated renal transplant patients, haemodialysis

Urology Unit, Department of Surgery, Hammersmith Hospital and Royal Postgraduate Medical School, Ducane Road, London W12 OHS

R. N. P. CARROLL, F.R.C.s., Urology Registrar (Now Consultant Urologist, Manchester Royal Infirmary)

E. P. N. O'DONOGHEU, F.R.C.S., Urology Registrar

R. SHACKMAN, F.R.C.S., Professor of Urology

Clinical Research Unit, Glaxo Laboratories Ltd., Greenford Middlesex

S. D. MARSH, M.SC., B.PHARM., Research Assistant (Now Clinical Trial Officer, Allen and Hanbury's Research)

Evans Biologicals Ltd., Speke, Liverpool

D. C. BREEZE, PH.D., M.I.BIOL., Technical Director patients, and controls with a half-strength vaccine against Hong Kong influenza. Because some of the transplant patients showed a protective rise in antibody response we subsequently vaccinated a further group of transplant patients with a stronger vaccine in the winter of 1970-1. We report here the results of the stronger vaccine.

\section{Subjects and Methods}

Control Group.- - Seventeen members of the medical and nursing staff volunteered as a control group for vaccination.

Transplant Group.-Twenty-five transplant patients who had received their grafts six months-four years earlier volunteered for vaccination. They were receiving maintenance doses of prednisone $15 \mathrm{mg}$ and azathioprine $100-200 \mathrm{mg}$ daily depending on body weight and their susceptibility to leucopenia.

Vaccine.-The vaccine consisted of 400 IU of A/Hong Kong/ $1 / 68\left(\mathrm{H}_{3} \mathrm{~N}_{2}\right)$ and $200 \mathrm{IU}$ of $\mathrm{B} /$ England/5/66 (Admune, manufactured for B.D.H. Pharmaceuticals, ${ }^{*}$ London, by Evans Medical Limited, Speke, Liverpool). The vaccine was manufactured to the then current British Pharmocopoeia and Therapeutic Substances Act regulations.

Sera.-Before vaccination and at one, three, and 12 months after vaccination blood was withdrawn for antibody titre and serum creatinine estimations. Serum was removed from coagulated whole blood after centrifugation and stored at $-30^{\circ} \mathrm{C}$. Each serum was treated with cholera flitrate to remove nonspecific inhibitors. Serum $(0.2 \mathrm{ml})$ and cholera filtrate $(1 \mathrm{ml})$ were incubated for 18 hours at $37^{\circ} \mathrm{C}$ in a water bath. Subsequently, each serum-cholera filtrate mixture was inactivated at $56^{\circ} \mathrm{C}$ for one hour in a water bath. The treated serum was taken as a $1 / 6$ dilution in calculating the results.

Haemagglutination Inhibition Test.-Serial dilutions of each *Now known as Duncan Flockhart and Co. Ltd. 
serum were made in $0.25 \mathrm{ml}$ volumes of saline. Influenza virus $(0.25 \mathrm{ml})$ was then added to each cup. The virus had been previously titrated and diluted to give 8 haemagglutinating units $/ 0.25 \mathrm{ml}$. Serum-virus mixtures were left undisturbed on the bench for 30 minutes then $0.25 \mathrm{ml}$ of $0.5 \%$ chicken cells were added. The end point of the test was taken as the first cup showing $100 \%$ haemagglutination, and the results were expressed as a reciprocal of the serum dilution present in that cup. A control virus titration was performed with each test.

Chicken Red Blood Cells.-Red blood cells from chickens were prepared as a $0.5-\mathrm{ml}$ suspension in saline and tested. Red blood cells which were agglutinated by vaccine virus were not used. Cells which were not agglutinated by that test were then used in a control titration against the previously used red blood cell suspension and a standard virus preparation. Those red blood cells which did not give a titration equal to the previously used cells against the standard virus preparation were discarded.

Plates.-Standard W.H.O. haemagglutination plastic plates were used.

\section{Results}

Though a combined vaccine containing A and B influenza strains was used for inoculation the antibody results are reported with respect of the major A strain component only.

Antibody levels $>96$ haemagglutination inhibition (H.I.) units, irrespective of the primary absolute values, or fourfold increases of the prevaccination values were taken as evidence of protection (Hobson et al., 1973). Using these criteria the results in the controls and the transplanted patients fall into four groups as follows (see table I).

TABLE I-Numbers of Controls and Transplant Patients in each of four Groups defined by Antibody Response to A/Hong Kong/1/68.

\begin{tabular}{l|l|l|l|l|l|l}
\hline \multicolumn{2}{l|}{ A Antibody titre group } & 1 & 2 & 3 & 4 & Total \\
\hline Controls . .... & $\ldots$ & 6 & 5 & 5 & 1 & 17 \\
Transplant patients &. & 7 & 9 & 6 & 3 & 25 \\
\hline
\end{tabular}

Group 1.-Consisted of those who were protected before innoculation-that is, those with levels $>96$ H.I. units-and remained protected throughout the whole 12-month period.

Group 2.-Consisted of those who were susceptible to infection before inoculation-that is, those with levels < 96 H.I. units-but responded to vaccination with increased levels of antibody at one, three, and 12 months ( $>96$ H.I. units.).

Group 3.-Consisted of those who showed a transient rise in antibody level to $>96$ H.I. units after vaccination which was not maintained over the 12-month period.

Group 4.-Consisted of those who showed no response to vaccination and remained susceptible to infection throughout the 12-month period.

Before vaccination 7 (41\%) of the 17 controls and $8(32 \%)$ of the 25 transplant patients had protective levels of antibody. After one month protective levels were detected in $16(94 \%)$ of the

TABLE II-Geometric Mean Titres in Controls and Transplant Patients before and one, three, and 12 Months after Vaccination

\begin{tabular}{|c|c|c|c|c|}
\hline \multirow{2}{*}{$\begin{array}{l}\text { A Antibody Titre } \\
\text { Groups }\end{array}$} & \multirow{2}{*}{$\begin{array}{c}\text { Before } \\
\text { Vaccination }\end{array}$} & \multicolumn{3}{|c|}{ After Vaccination } \\
\hline & & 1 Month & 3 Months & 12 Months \\
\hline $\begin{array}{l}\text { Controls } \\
\text { Transplant patients }\end{array}$ & $\begin{array}{l}305 \\
212\end{array}$ & $\begin{array}{l}862 \\
424\end{array}$ & $\begin{array}{l}121 \\
384\end{array}$ & $\begin{array}{l}221 \\
468\end{array}$ \\
\hline $\begin{array}{l}\text { Controls } \\
\text { Transplant patients }\end{array}$ & $\begin{array}{l}28 \\
16\end{array}$ & $\begin{array}{r}1,536 \\
711\end{array}$ & $\begin{array}{l}114 \\
609\end{array}$ & $\begin{array}{l}145 \\
415\end{array}$ \\
\hline $\begin{array}{l}\text { Controls } \\
\text { Transplant patients }\end{array}$ & $\begin{array}{l}18 \\
17\end{array}$ & $\begin{array}{l}253 \\
216\end{array}$ & $\begin{array}{l}28 \\
68\end{array}$ & $\begin{array}{l}48 \\
34\end{array}$ \\
\hline $\begin{array}{l}\text { Controls } \\
\text { Transplant patients }\end{array}$ & $\begin{array}{l}24 \\
15\end{array}$ & $\begin{array}{l}48 \\
24\end{array}$ & $\begin{array}{l}24 \\
30\end{array}$ & $\begin{array}{l}48 \\
38\end{array}$ \\
\hline
\end{tabular}

controls and in $22(88 \%)$ of the transplanted patients. At three months protective levels were detected in nine $(56 \%)$ out of 16 controls and $18(72 \%)$ of the transplanted patients. At 12 months protective levels were detected in $11(79 \%)$ out of 14 controls and $18(72 \%)$ of the transplanted patients. The decreasing total numbers of controls reflected follow-up failures. The geometric mean titres before and at one, three, and 12 months after vaccination in all subjects are given in table II.

When the antibody response to vaccination was correlated with the degree of renal function in the transplanted patients significant responses were observed in six out of 15 with good function (serum creatinine $0.9-1.4 \mathrm{mg} / 100 \mathrm{ml}$ ), two out of six with moderate function (serum creatinine $1.8-2.5 \mathrm{mg} / 100 \mathrm{ml}$ ), and one out of four with poor function (serum creatinine $3 \cdot 0-6 \cdot 0 \mathrm{mg} / 100 \mathrm{ml}$ ) (table III). In seven other patients there was protection before vaccination and the protection persisted in all seven after three and after 12 months. In six other patients only transient significant responses were observed, and in three others no evidence of protection could be detected throughout.

TABLE III-Relation between Kidney Transplant Function and Antibody Titre Groups in 25 Patients

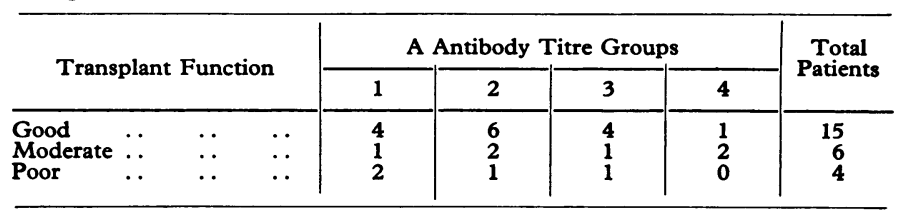

\section{Discussion}

The qualitative pattern of response of both controls and transplant patients was similar. Of seven in the transplant group who started with antibody titres at protective levels (Hobson et al., 1973) six responded to vaccination by showing increases in antibody titre. Of the remaining 18 who showed no protective levels before vaccination nine responded well to inoculation and maintained protective levels throughout the 12-month period, six showed a transient rise to protective levels which were not maintained, and three failed to respond. One month after vaccination $94.1 \%$ of the controls showed protective levels compared with $88.0 \%$ of the transplanted patients and at three months the figures were $56.3 \%$ and $72.0 \%$ respectively. At 12 months there was an increase in the number of controls with protective levels of antibodies, which almost certainly reflected clinical exposure to influenza. Similarly in the transplant patients, in whom the protective figure remained at $72 \%$ after one year, clinical infection probably accounted for subsequent rises in antibody titres in some patients after 12 months. The quantitative responses were measured as geometric mean titres to describe the centre of distribution of the antibody groups. When this was done the initial antibody response to vaccination was found to be slightly higher in the controls (see table II). At three and 12 months, however, the antibody response was better in the transplant patients, and covariance analysis of the individual results showed a negative correlation; lower preinoculation titres resulted in a larger area under the postvaccination titre "curves," and high preinoculation levels resulted in smaller areas after vaccination. Since the preinoculation titres of the two groups were different the main areas under the curves were adjusted, and the adjusted response mean for the control group was 15.4 while that for the transplant group was $28 \cdot 1$, the difference being statistically significant $(t=2 \cdot 11, \mathrm{P}=0.05)$. The higher antibody responses in the transplant group after three and 12 months may have been caused by a diminished rate of break down of antibody in immunosuppressed patients.

The interpretation of the covariance analysis must be treated with caution. Sera were assayed on receipt in the laboratory and day-to-day variation in this type of assay is well known. The 
analysis does not take this into account. Nevertheless, with the precautions taken, in the experience of the assay laboratory, such variation alone would be unlikely to account for the results obtained.

Transplant function was arbitrarily defined as good, moderate, and poor, and the patients in these subgroups were fairly evenly distributed in respect of antibody titre groups. Though the numbers were small it is reasonable to claim that there was no correlation between the degrees of renal function and the response to vaccination. Moreover, the response to vaccination in the transplant patients seemed to be unrelated to the length of time since transplantation or to the total administered doses of prednisone used for immunosuppression. None of the patients whose transplant function was classified as good or moderate showed any evidence of rejection episodes after vaccination, but the four patients whose renal function was classified as poor, and who had clinical and biochemical evidence of rejection before vaccination, continued to reject their kidneys after vaccination and three had to be returned to the haemodialysis programme before the end of the 12-month period. None of the controls or the transplant patients reported or was considered to have had a clinical illness suggestive of influenza in the three months after vaccination.

When compared with the controls, who were not receiving immunosuppressive therapy, the IgG levels were significantly lower in the transplant patients who were receiving immunosuppressive therapy. The difference was apparent both before and after vaccination (Ross 1972).

The results suggest that it is safe to vaccinate kidney transplant patients with inactivated influenza vaccine and that a measure of protection can be achieved despite immunosuppressive therapy without increasing the risk of graft rejection. In view of the reported association between viral infections and transplant rejection (Simmons et al., 1970; David et al., 1972; Briggs et al., 1972) this protection may have special significance.

We thank Mr. J. Kerr and his colleagues in the virus assay unit, Evans Medical, Speke, Liverpool, for the H.I. tests. We also acknowledge the help of Dr. W. L. Burland and Mrs. Gillian A. Rose of Glaxo.

\section{References}

Briggs, J. D., et al. (1972). British Medical fournal, 4, 520.

David, D. S., et al. (1972). Annals of Surgery, 175, 257

Hobson, D., Curry, R. L., and Beare, A. S. (1973). In International Symposium on Influenza Vaccines for Men and Horses, ed. F. T. Perkins and R. H. Regamly, p. 164. Basel, Karger.

Ross, G. W. (1972). Personal communication.

Simmons, R. L., et al. (1970). Transplantation Proceedings, 2, 419.

\section{MEDICAL MEMORANDA}

\section{Acute Upper Respiratory Tract Obstruction Complicating Childhood Leukaemia}

\section{P. MORRIS, E. A. SHAW}

British Medical fournal, 1974, 2, 703-704

Though acute leukaemia in children is still a fatal disease an aggressive approach to treatment has much increased the duration of survival (British Medical fournal, 1973). Some $50 \%$ of children can be expected to live for five years (Pinkel, 1972) and in $50 \%$ of all cases neurological complications will develop during treatment (Sinks, 1972). With longer survival potentially fatal crises may be expected to occur in other systems (Sherman et al., 1973). The two cases reported here show that these crises should not be regarded as preterminal and that appropriate treatment should be given.

\section{Case 1}

The patient was a $3 \frac{1}{2}$-year-old girl in whom acute lymphoblastic leukaemia had been diagnosed 18 months previously. Remission had been induced with vincristine and prednisolone. In a relapse 13 months later remission was obtained with cytarabine and daunorubicin. A further relapse three months before admission did not respond to cytotoxic agents but prednisolone was continued.

Royal Manchester Children's Hospital, Pendlebury, Nr. Manchester M27 1HA

P. MORRIS, M.B., F.F.A. R.C.S., Consultant Anaesthetist

E. A. SHAW, M.B., F.F.A., R.C.S., Consultant Anaesthetist
On admission she had a dry cough, vomiting, pyrexia $\left(38.6^{\circ} \mathrm{C}\right)$, tachycardia, and a monilial infection of the mouth and posterior pharyngeal wall. She was treated with intravenous gentamicin and oral nystatin. The next day her condition deteriorated and there were signs of circulatory failure. Treatment with hydrocortisone, fusidic acid, and intravenous fluids was started. Investigations showed $\mathrm{Hb} 15.8 \mathrm{~g} / 100 \mathrm{ml}$; white blood cells $800 / \mathrm{mm}^{3}$ (neutrophils $26 \%$, lymphocytes $68 \%$, monocytes $4 \%$ ); and platelets $21,000 / \mathrm{mm}^{3}$. Blood culture grew Streptococcus pneumoniae sensitive to fusidic acid. Serum electrolyte values were $\mathrm{Na} 130 \mathrm{mEq} / 1 ., \mathrm{K} 3.5 \mathrm{mEq} / 1$., $\mathrm{Cl} 92 \mathrm{mEq} / 1$., $\mathrm{HCO}_{3} 17 \mathrm{mEq} / 1$., urea $39 \mathrm{mg} / 100 \mathrm{ml}$.

Her condition improved, but after two days she suddenly developed upper respiratory obstruction with a pool of mucus in the posterior oropharynx and a blue swelling visible on the posterior pharyngeal wall when she retched. A retropharyngeal haematoma was diagnosed. Within three hours increasing obstruction required the insertion of an airway. Pharyngolaryngoscopy showed a large, blue haemorrhagic swelling involving the right posterior pharyngeal wall, valecullae, both aryepiglottic folds, and spreading into the right pyriform fossa. The laryngeal vestibule was reduced to a small slit and the vocal cords were obscured. There were large white patches of monilia in the pharynx and larynx. A plastic nasotracheal tube, internal diameter $5.5 \mathrm{~mm}$, was passed with some difficulty. After recovering consciousness she was nursed in a mist tent containing $30 \%$ oxygen. The nasotracheal tube was well tolerated without sedation and respiratory obstruction was relieved. During the next 48 hours her condition improved, but large bruises developed over the legs, the right side of the neck, and the trunk. Melaena stools were passed. A blood count showed $\mathrm{Hb}$ $8.1 \mathrm{~g} / 100 \mathrm{ml}$; W.B.C. $600 / \mathrm{mm}^{3}$ (neutrophils $54 \%$, lymphocytes $44 \%$, blast cells $2 \%$ ); and platelets $8,000 / \mathrm{mm}^{3}$. Four units of platelets and two of blood were given.

Within 72 hours of intubation she had improved. Pharyngolaryngoscopy showed that the haemorrhagic swelling had resolved apart from thickening of the aryepiglottic folds. Patches of monilia were still visible. On removing the endotracheal tube the vocal cords and subglottic region were easily seen and appeared normal. Her immediate postoperative recovery was uneventful. After 56 hours, however, generalized convulsions occurred and lumbar puncture produced heavily blood-stained crebrospinal fluid. She died 36 hours later. Necropsy showed evidence of leukaemia with a left retroperitoneal haemorrhage and a subarachnoid haemorrhage over the left parietal lobe. Haemorrhagic areas were seen beneath 